\title{
Development of early literacy skills: A Comparison of two early literacy programmes
}

\author{
Zuzana Petrová, Ol'ga Zápotočná, Kamila Urban, Marek Urban
}

Abstract: The aim of the present study is to monitor the effectiveness of a new conception of early literacy curriculum (in force since September 2016) which provides - unlike the previous one - a wide range of purposeful literacy practices and literacy events. The study compares graduates of previous early childhood literacy curriculum (tested in June 2016) with children who attended kindergarten in the years 2016-2019. Several indications of early literacy development were selected especially those that are culturally more sensitive, i.e. are significantly shaped by the social environment offering the broad spectrum of reading experiences. Results show statistically significant relationship of story listening comprehension with comprehension monitoring and narrative production, especially at the level of understanding the implicit meaning. The most profound group differences were found again in narratives and implicit meaning comprehension. On the other hand, no differences were found in indicators of phonemic awareness, comprehension monitoring and understanding the explicit meaning. The results are discussed in terms of their implications to educational practice.

Keywords: early literacy education, text comprehension, comprehension monitoring, narrative production, phonological awareness

Learning to read has long been held to be a necessary ingredient for success in school and life. But long before children are formally taught to read, and long before they become independent readers, they learn about the function and process of reading (Rohde, 2015). The concept of emergent literacy (Clay, 1966) is based on the idea that the period before formal reading instruction is a vital part of reading development and that children 
come to school with a great deal of knowledge about reading and writing and are able to apply their knowledge in a meaningful way. This finding, along with empirical evidence showing that children grow as readers and writers along a developmental continuum (Ferreiro \& Teberosky, 1982; Sulzby, 1992) led to the rejection of "reading readiness" - the notion that reading is primarily a decoding process, involving mastery of a skills hierarchy (Crawford, 1995). Instead of forcing formal reading, early childhood teachers are encouraged to provide opportunities for literacy-related play, literature and shared reading activities that give children the experience that will enable them to become more competent readers as they grow older (Saracho, 2017).

Although the concept of emergent literacy has been adopted worldwide, in Slovakia the first official attempt to introduce an early literacy curriculum (Pre-primary state education programme for preschools; NC, 2016) prompted heated discussion. Most of those arguing against any kind of early literacy experience suggested that the use of print materials and print related, invented reading and writing related activities in the classroom would pressurise children into starting reading prematurely and frustrate children who were not ready to read. When the new early childhood curriculum introducing emergent literacy as the core concept in early literacy practices was developed and introduced in Slovakia (between 2011 and 2016), there was a series of discussions between the main authors of the early childhood curriculum (including O. Zápotočná and $Z$. Petrová, co-authors of this paper) and early childhood professionals, education ministry agencies and professional organizations involved in early childhood education in Slovakia. Questions were raised as to whether it was not developmentally inappropriate and out of keeping with the national early childhood tradition to focus on literacy in children's lives and natural literacy development in a literacy rich environment (Petrová \& Zápotočná, 2018). The clash between the various early literacy perspectives in these discussions, took place on the one side between "maturity" proponents who believed that children needed to reach a certain level of maturity before beginning formal reading instruction and that hurrying children into learning to read could be highly damaging, and "developmentalists" who argued that children needed some pre-reading experience but not emergent reading and writing, while on the other side there were the "emergent" and "socio-constructionist" proponents advocating emergent literacy, whole language and authentic reading and writing experiences. The clash prompted researchers to investigate children's early experiences of reading and writing (Babjaková \&Venzelová, 2017; Belešová, 2017) and early literacy skills development (Duchovičová, Kováčiková, Khu- 
ziakhmetov \& Valeev, 2019; Máčajová, 2019; Máčajová \& Zajacová, 2018; Zápotočná \& Petrová, 2017).

The present paper contributes to that discussion and, drawing on the relevant empirical research, its main aim is to understand how the early literacy programme, with its "emergent literacy" foundation, operates in Slovak early childhood settings and how this particular conception of early literacy supports early literacy skill development.

\section{Slovakia's Pathway to an Early Literacy Curriculum}

Slovakia's pathway to an early literacy curriculum was laid out by local socio-cultural and political characteristics that shaped both the conception of the curriculum and the way in which early childhood professionals and practitioners conceive of everyday practice (Petrová \& Zápotočná, 2018). In Slovakia, reading and writing instruction has traditionally stressed the acquisition of letter-sound correspondences and their use in reading, with the main responsibility for teaching this lying with primary schools. Early childhood education was therefore seen as having a pivotal role in language development instruction. The main early childhood education goal concerning language development was a reflection of the diverse language backgrounds in the children's home environments. Interventions were designed to ensure every child learned the standard language to enable a smooth transition from the domestic and preschool oral culture to school culture. From 1965 to 2008, when the national curriculum underwent only minor revisions, the focus was on four aspects of speech development: pronunciation and grammar, vocabulary, and communication skills - conceived as discrete skills (Preschool education programme, 1999; PEP). It was also assumed that preschool children did not have the capacity, motivation or urge to understand reading and writing, that it was rare for children to have any early literacy skills and that they preferred play to reading and writing (Guziová, 2010/2011). Therefore, to ensure children's readiness for the reading and writing instruction in first grade, preschools focused on developing fine motor skills, particularly those required for handwriting (grapho-motoric skills), and on phonemic awareness in preparation for phonics instruction.

The role played by early literacy experiences in the transition from preschool culture to the school print-based culture was firstly formally recognized in the national early childhood curriculum of 2008 (State preschool education programme - ISCED 0; SPEP). However, it has yet to find its way into the conception of language development, remaining a declarative gen- 
eral goal of early childhood education. Previously the conception of language development stressed the traditional areas of language development and the role of phonemic awareness in learning to read, and grapho-motoric skills in learning to write, which were well-established in the previous national curriculum (PEP, 1999). It was only later, in the national early childhood curriculum issued in 2016 (NC, 2016) that early literacy development became a key goal of early childhood education and was included in the Language and Communication education area of the curriculum.

\section{Early Literacy Curriculum in Slovakia}

The early literacy curriculum as conceived of in Language and Communication education area of the national curriculum was developed to exploit the natural symbiosis between the spoken and written language. This symbiosis is rooted in the preschool traditions of language development and literary education, and reflect the more recent theoretical foundations of early literacy development. The early literacy curriculum was conceived of in response to two interrelated needs stemming from previous conceptions of the role early childhood education plays in children learning to read and write. First, the early literacy curriculum introduced a more comprehensive model that included knowledge and abilities relating to emergent literacy skills. Second, the early literacy curriculum presented emergent literacy as the interaction between skills and context within the given learning environment and the provision of opportunities for children to learn about literacy.

The theoretical and empirical underpinning of the preschool literacy curriculum was derived from the main theoretical models of reading and literacy in cognitive psychology (cognitive processing and text comprehension based reading models developed in the 1970s), from contemporary approaches to literacy associated with the sociocultural turn (the British school of New Literacy Studies, Street, 1984; and Gee, 2004), as well as the Vygotskian approach to education (Petrová, 2008), in its more recent adaptations for early childhood education (Bodrova \& Leong, 2006). These approaches have contributed to literacy theory such that, instead of literacy being understood as a distinct cognitive activity unique to the individual and represented in traditional approaches to reading, the social, cultural and situational context is now considered significant (Zápotočná, 2004). As a result, there has been a notable shift away from the established approaches to literacy education - reading and writing instruction - and towards a literacy education that emphasizes literacy practices and literacy events (Street, 1997).

The concept of emergent literacy is particularly relevant to early child- 
hood education. It is the idea that a literacy-rich environment provides children with opportunities and reasons for exploring print and writing through spontaneous cognitive activity, which leads to the gradual acquisition of literacy (Black \& Ammon, 1992), and that the acquisition of pre-conventional writing is the result of meaning-making and over time develops into the ability to read and write (Ferreiro, 2003).

Slovakia's previous preschool curricula lacked explicit goals and frameworks for targeting written language and literacy in early childhood education. Consequently, early childhood teachers had limited experience of providing a literacy-rich environment in the classroom and of encouraging preschoolers to explore the written language. Therefore the new framework of early literacy development had to be introduced in great detail. A more comprehensive model of early literacy skills was adopted to ensure that teachers would have a solid knowledge base of early literacy and child development.

The definition of early literacy skills used in the curriculum was mainly influenced by van Kleeck's $(1995 ; 1998)$ model of Pre-literacy Domains and Stages that represents the wide spectrum of reading components (abilities, skills, knowledge and experiences). In this model, four hypothetical processors are involved in the reading process (Adams, 1990). Two of these - the context processor and the meaning processor - explore the meaning of print; and the remaining two - the orthographic and phonological processors - explore the form. They could be used to target specific early literacy abilities, skills, knowledge and experience at preschool age. This model also assumes literacy development is a natural sequence, beginning from understanding the contextual and meaning components of print (initial stage), progressing to the natural and spontaneous discovery of meaning-to-form relations and correspondence (next stage), and continuing with gradual improvements in processing the form (i.e. the orthography and phonology of the written language). In the last stage, the child - by this stage an autonomous reader at primary school level - will be able to draw on abilities, experience and knowledge developed in the previous stages of literacy development.

Specifically, the early literacy curriculum targets two main subareas: "spoken language" and the "written word and written culture". In "spoken language", alongside the previous objectives regarding articulation and pronunciation and the correct use of grammar and standard spoken language, emphasis is also placed on the social appropriacy of language use and adherence to the conventions of communication. The framework curriculum also 
includes a section containing specific objectives relating to exploring the "written word and written culture". The initial emphasis is on building up experience of the content - the meaning and function of the written word, which includes experience of text use in different contexts and of various genres and text comprehension, in terms of understanding both the explicit and implicit meanings in the text. Following on from this is the acquisition of experience, knowledge and abilities relating to the formal characteristics of the written language and written culture. Having previous experience of the content is therefore important, as is gaining subsequent and increasingly rich experiences of form along with opportunities for exploration, discovery and understanding. This education area includes phonology (phonemic awareness) and grapho-motoric skills, and contains sub-areas such as familiarisation with writing and text conventions and developing concepts about print.

To ensure that teachers are able to provide a broad range of relevant literacy experiences for children, it is recommended that a rich variety of literature genres be used (Musiello, 1994). In that way the children's diverse needs and interests can be met (Costa, 1994) and meaningful and socially relevant engagement with books, and developmentally appropriate experiences of literature can be provided across all the domains and areas in the early childhood curriculum (Chaplin, 1994). A wide variety of literature genres is recommended so multiple aims can be met:

- Literature genres offer a source of rich language experiences that can serve as language models and contain various educated and developed examples of standard first language use. They help children develop spoken language and communication skills, and are a means of stimulating all areas of language development - vocabulary and syntax, appropriate use of grammar, standard language and socially appropriate forms of expression.

- They provide a rich source of linguistic knowledge that can be used to help develop all the key developmental foundations of literacy (listening and reading comprehension, understanding the meaning and function of the written word, awareness of the relationship between spoken and written forms of language) in terms of both content and form.

- They are an important source of positive experiences, foster motivation and promote interest in and a relationship with the written culture, education and learning. 
The use of a wide variety of literature provides children with opportunities to expand their knowledge as stories introduce situations, locations, feelings and problems that children have not yet encountered (van der Wilt, Boerma, van Oers \& van der Veen, 2019). Both fiction and non-fiction texts are an important means of integrating content from different educational areas. From the long-term perspective, the purposeful use of texts covering a wide range of educational content is essential to developing cultural literacy, understanding the cognitive and educational function of language, especially written language, and inculcating good reading habits and fostering understanding of the print based school education.

As teachers are also encouraged to use shared book reading activities (Mol, Bus \& de Jong, 2009), children experience literacy as a more comprehensive segment of human culture. Shared book reading activities encourage children to play a more active role in reading by providing opportunities for them to engage with the story, ask questions and to experience reading as an exciting, personally relevant endeavour embedded within the social and cultural context.

\section{Purpose of the Study}

The present study is based on work relating to three major aspects of the Slovak early literacy curriculum relating to children's early literacy development. The first is the recognition that there is a need to carefully and comprehensively introduce children to key early literacy experiences, via the national early literacy curriculum, so as to provide them with balanced literacy experiences. The second is that children should be exposed to a wide variety of literature genres to ensure literacy development draws on multiple contexts and to motivate them to read and write for enjoyment as well as being a source of information and means of communication. And the third is to encourage teachers to adopt shared book reading practices that present reading as a meaning-making process and to actively engage children in reading and allow them to ask questions and talk about their ideas and experiences in relation to the story. As the new early literacy curriculum is designed to promote more comprehensive and more individually relevant literacy experiences and ensure that children acquire knowledge through being actively involved in literacy practices, the expectation is that it will lay down a specific developmental pathway of literacy acquisition in children.

This study is concerned with monitoring the effectiveness of the implementation of the new early literacy curriculum (NC, 2016), which has been 
in force since September 2016. The aim of the study is to compare children who followed the previous early childhood curriculum (tested in June 2016) with children who attended preschool in 2016-2019. We assume that children educated according to the new Pre-primary State Education Programme for Preschools will perform better in the early literacy indicators monitored, as the new curriculum provides for a wide range of literacy practice and literacy events. The research will focus on the literacy development indicators that are significantly shaped by the social and cultural environment, depending on the broad spectrum of language experiences associated with reading.

\section{Method}

\section{Participants}

The sample consisted of a total of 426 preschool children aged 61 to 89 months old ( $M$ age $=75$ months, $S D=5.85)$. All the children were native Slovak speakers from middle-income families. The participants were recruited and tested in public preschools in all eight Slovak regions. Written consent was obtained from the children's parents and verbal assent from the children before testing.

The sample was composed of two groups of children of the same age. The first group ( $N=327,151$ boys and 176 girls) was tested in June 2016 and were from the last year of children to follow the previous preschool education programme (SPEP, 2008). The second group ( $N=99,52$ boys and 47 girls) was tested in June 2019. The second group of children was selected based on a detailed survey of the characteristics of their preschool education environment. The preschool selection criteria were based on the implementation of the new national early childhood curriculum (NC, 2016), including the newly elaborated Language and Communication education area (Zápotočná \& Petrová, 2016). Children from preschools demonstrating excellence in following the programme were selected.

The a priori statistical power analysis for expected effect size $r=0.4$, a (two-tailed) $=0.05$ a $\beta=0.2$ (Chow, Shao, Wang \& Lokhnygina, 2017) indicated there was a sufficient number of children in both groups.

\section{Materials}

The literacy predictors were measured using two subtests from the Liter- 
acy Predictors Battery (Mikulajová, Caravolas, Váryová \& Vencelová, 2012). These subtests are considered to be indicators of preliteracy skills and are sensitive to impaired speech development.

The phonemic awareness (hereafter PA) subtest contains three categories of tasks (syllable segmentation, phoneme isolation and phoneme blending), each containing five tasks. Children receive one point for each correctly solved task and the final PA score is the sum of points received (max 15).

The pseudowords repetition task (hereafter pseudowords) contains five pseudowords and children receive one point for each correctly pronounced word. Pseudowords are easily pronounceable for speakers of the language but difficult for children with language and reading disabilities.

Text comprehension (hereafter Story) was assessed using a story called "O vtáčikoch" [About the little birds] (Benková, 2012). The children were tested while an experimenter read them the story. The Story contains five questions related to the explicit (literal) meaning of the text and eight questions on implicit meaning. Children can receive a maximum of 28.5 points: 10.5 for explicit meaning and 18 for implicit meaning. Responses are scored as fully correct ( 2 or 2.5 points), partially correct (from 0.5 to 1.5 points) or incorrect ( 0 points).

Comprehension monitoring (hereafter $\mathrm{CM}$ ) test contained four short texts: two texts monitoring narrative consistency and two monitoring inconsistencies in the texts. The test was prepared for Slovak speakers using examples from Kim and Phillips (2014). The test measures the children's ability to reflect on their comprehension of the text. The children respond to a problematic message by indicating whether it is a 'good' message or not. For each correct response children receive one point $(\max 4)$.

Narrative production (hereafter narratives) was monitored by means of two picture story sequences "Zajačik a konik" [Bunny and the little horse] and "Balón” [Balloon] (Marková, 2011; Zápotočná \& Petrová, 2017). The analyses consisted in identifying the total number of words produced, words produced only once during the narration (hereafter number of unique words), narrative structure (hereafter global structure) and mean number of components used in the narration (the components are: setting, characters, initiating event, problem, complication or attempt at resolution, resolution and motivation). The level of narrative production in the preschool predicts reading skills in later school age (Pyšná \& Kapalková, 2012). 
These last three indicators of early literacy development (i.e. text comprehension, comprehension monitoring and narrative production) are more culturally sensitive and, compared to phonemic awareness (and other literacy predictors), have longer-term predictive validity in relation to the acquisition of reading literacy skills in later school age (Bianco et al., 2012; Dufva \& Niemi, 2001).

\section{Procedure}

The authors and a trained student experimenter tested the children individually in a separate room in their preschool. The procedure was the same for all children; the order of tasks was randomized.

The phonemic awareness subtest and the pseudowords repetition task were administered together: children were asked to divide the five words into syllables, to identify the first phoneme of the five words, to identify five words by their isolated phonemes and to repeat five pseudowords.

For the story comprehension task, the experimenter explained that she was going to read a story to the child and ask questions while reading, so it was important that the child listened carefully so he or she would be able to answer the questions.

Before the comprehension monitoring test was administered, the children were given two examples to ensure they understood the comprehension task (one example was a consistent story and the other example contained an inconsistent statement about the story). Then, the children completed four comprehension monitoring tasks.

The experimenter introduced the narrative production tasks by pointing at each of four pictures from the story "Balloon" and asked the child to say what happened in the story. When the child had finished, the experimenter asked two comprehension questions and then the same procedure was repeated with the "Bunny and Little Horse" story.

\section{Results}

Table 1 shows the average values of the variables from the whole dataset and shows the relationships between the individual variables. We can see that all the early literacy development indicators are intercorrelated. The strongest relationships are found between the individual measures of nar- 
rative production, indicating the consistency of the measure. More importantly, narrative production correlates moderately with text comprehension, especially with understanding the implicit meaning of the stories. As can be seen, the correlations with the phonemic awareness indicators are lower.

Comprehension monitoring has the strongest relationships with text comprehension, and the relationship with understanding implicit meaning is the stronger than the relationship with understanding explicit meaning. Both text comprehension indicators are similarly correlated with phonemic awareness.

Table 1 Descriptive statistics and linear correlations (Pearson's r)

\begin{tabular}{|c|c|c|c|c|c|c|c|c|c|c|c|}
\hline & & $M(\mathrm{SD})$ & 1. & 2. & 3. & 4. & 5. & 6. & 7. & 8. & 9. \\
\hline 1. & Pseudowords & $4.58(0.79)$ & 1 & & & & & & & & \\
\hline 2. & Phonemic awareness & $11.29(3.12)$ & $.261^{* * *}$ & 1 & & & & & & & \\
\hline 3. & $\begin{array}{l}\text { Comprehension } \\
\text { monitoring }\end{array}$ & $3.11(0.89)$ & $.203^{* * *}$ & $.326^{* * *}$ & 1 & & & & & & \\
\hline 4. & $\begin{array}{l}\text { Narratives: total } \\
\text { number of words }\end{array}$ & $30.28(17.72)$ & $.152^{* *}$ & $.192^{* \star *}$ & $.205^{\star * *}$ & 1 & & & & & \\
\hline 5. & $\begin{array}{l}\text { Narratives: unique } \\
\text { words }\end{array}$ & 21.41 (9.33) & $.189^{* * *}$ & $.252^{* \star *}$ & $.240^{* * *}$ & $.947^{* * *}$ & 1 & & & & \\
\hline 6. & $\begin{array}{l}\text { Narratives: global } \\
\text { structure }\end{array}$ & $2.22(0.66)$ & $.185^{* * *}$ & $.262^{* * *}$ & $.200^{* * *}$ & $.561^{* * *}$ & $.639^{* * *}$ & 1 & & & \\
\hline 7. & $\begin{array}{l}\text { Narratives: } \\
\text { components }\end{array}$ & $4.79(1.00)$ & $.147^{* *}$ & $.305^{* * *}$ & $.280^{* * *}$ & $.692^{* \star *}$ & $.751^{* * *}$ & $.576^{* * *}$ & 1 & & \\
\hline 8. & Story: explicit meaning & $5.14(1.46)$ & $.188^{* * *}$ & $.386^{* * *}$ & $.325^{* * *}$ & $.350^{* * *}$ & $.380^{* * *}$ & $.256^{* * *+}$ & $.384^{* * * *}$ & 1 & \\
\hline 9. & Story: implicit meaning & 8.33 (2.99) & $.275^{* * *}$ & $.446^{* * *}$ & $.388^{* * \star}$ & $.408^{* * *}$ & $.447^{* * *}$ & $.386^{* * *}$ & $.433^{* * *}$ & $.548^{* * * *}$ & 1 \\
\hline
\end{tabular}

Note. ${ }^{* * *} p<.001,{ }^{* *} p<.01$.

In order to examine the differences between the two groups of children (tested in 2016 and 2019) we performed a MANOVA with the dependent variables listed in Table 2 . The effect size of the year of testing was very large, $F(9,367)=10.286, p<.001, \mathrm{\eta}_{p}^{2}=.201$. To identify changes in the individual variables, we performed separate one-way ANOVAs, as reported in Table 2.

As we can see, the most profound difference between the two groups of children following different national curriculum for preschool education (tested in 2016 and 2019) was in narratives and implicit text comprehension. This finding indicates that the new approaches to reading in the new preschool curriculum mainly led to an improvement in understanding implicit meaning and narrative production. There were no differences in phonemic 
Table 2 Results of one-way ANOVAs between performances in 2016 and 2019

\begin{tabular}{|l|l|l|l|l|l|l|}
\hline \multicolumn{2}{|c|}{ Year of testing: } & \multicolumn{2}{c}{2016} & 2019 & \multicolumn{3}{c|}{ ANOVA } \\
\cline { 3 - 7 } & $M(\mathrm{SD})$ & $M(\mathrm{SD})$ & $F$ & $p$ & $\eta_{p}{ }^{2}$ \\
\hline 1. & Pseudowords & $4.51(0.84)$ & $4.81(0.55)$ & 11.139 & $<.001$ & .026 \\
\hline 2. & Phonemic awareness & $11.18(3.20)$ & $11.64(2.81)$ & 1.664 & .198 & .004 \\
\hline 3. & Comprehension monitoring & $3.12(0.89)$ & $3.08(0.89)$ & 0.181 & .671 & .000 \\
\hline 4. & Narratives: total number of words & $27.03(13.46)$ & $39.72(24.19)$ & 41.739 & $<.001$ & .098 \\
\hline 5. & Narratives: unique words & $19.92(8.12)$ & $25.69(11.11)$ & 30.238 & $<.001$ & .074 \\
\hline 6. & Narratives: global structure & $2.11(0.69)$ & $2.56(0.43)$ & 38.224 & $<.001$ & .091 \\
\hline 7. & Narratives: components & $4.71(0.95)$ & $5.02(1.11)$ & 7.147 & .008 & .018 \\
\hline 8. & Story: explicit meaning & $5.07(1.48)$ & $5.36(1.38)$ & 3.041 & .082 & .007 \\
\hline 9. & Story: implicit meaning & $7.94(2.90)$ & $9.61(2.91)$ & 25.123 & $<.001$ & .056 \\
\hline
\end{tabular}

awareness, comprehension monitoring or understanding explicit meaning. The practical implications are discussed in the next section.

\section{Discussion}

In the present study we analysed several early literacy indicators in children in two different early childhood settings following a different early literacy curriculum - one in force from 2008 and the other one in force since 2016 - to ascertain how effective the new early literacy curriculum is. In this paper we presented a correlation matrix of selected indicators and compare two data sets (relating to children tested in 2016 and children tested in 2019) using separate one-way ANOVAs.

\section{Correlational relationship}

The systematically statistically relevant relationships between narrative production and text comprehension, particularly in implicit text comprehension, indicate that these early literacy indicators share a common factor, usually a literacy rich environment. This is supported by empirical research indicating that both narrative production (Kapalková \& Nemcová, 2020) and text comprehension (Bianco et al., 2012; Fricke et al., 2016), which are closely interlinked at preschool age (Cain, 2003), are extremely reliable predictors of future literacy development and school attainment.

On the other hand phonemic awareness does not have a high predictive 
validity. The little that has been found relates mostly to the basal reading processes in the initial phase of reading involved in word decoding processes (Landerl \& Wimmer, 2008). It is only indirectly related to text comprehension, in the sense that phonemic awareness facilitates mastery of reading technique (related to text decoding) and correlates more strongly with explicit text comprehension (Fricke et al., 2016; Zápotočná, 2017) which involves short-term memory word recall (Tokárová \& Mikulajová, 2018). In our study the relationship between phonemic awareness and text comprehension can be attributed to the fact that text comprehension was investigated as listening comprehension (Torppa et al., 2016). On the other hand the weak correlations between phonemic awareness and narrative production indicate that phonemic awareness plays a less significant role than the broad spectrum of linguistic, cognitive, literary, social and emotional experience reflected in children's narrative abilities (Kapalková \& Nemcová, 2020).

Regarding the comprehension monitoring task indicating the children's ability to think about or monitor their listening comprehension, the analyses showed this correlated strongest with text comprehension, especially implicit text comprehension, which corresponds to previous research findings about the role of metacognitive processes in reading (Zápotočná, 2013). There has been little research in early childhood and preschool age in this field, although interest in this research topic is growing, especially in education (Revelle, Wellman, \& Karabenick, 1985; Urban, 2017; van Kleeck, 2014)

\section{Group differences}

The main objective of our study was to examine how selected early literacy skills develop before school entry in children attending two different early literacy programmes. Our assumption that children achieve better results if they have attended the new early literacy programme (NC, 2016) was not met, as indicated only by one of the early literacy indicators - comprehension monitoring tasks. This result may have been affected by the psychometric parameters of the diagnostic tool used in our study. Previous studies in this field have shown that when children perform a task their metacognitive processes are involved profided that effective intervention strategies exist in this field (Destan \& Roebers, 2015; Lyons \& Ghetti, 2011; Urban, K., \& Urban, M., 2018, 2020). We therefore assume that there is potential that Slovak preschools could target. Despite the evidence that early childhood teachers have incorporated various literacy practices and literacy events into their everyday classroom activities, there is a need to examine how teachers me- 
diate children's thinking about the text and how they create a literacy rich environment, including a metacognitive environment.

Turning to the other indicators (text comprehension and narrative production), the one-way ANOVAs showed there was a high significant difference between the groups in both tasks, with the children attending the new early literacy programme (NC, 2016) performing better. For total number of words $\left(\mathrm{n}_{p}^{2}=.098\right)$, number of unique words in narratives $\left(\mathrm{\eta}_{p}^{2}=.074\right)$ and global structure of narratives $\left(\mathrm{n}_{p}^{2}=.091\right)$, the results were statistically significant, $p<.001$. The differences in the text comprehension measures were greatest in relation to implicit text comprehension $\left(p<.001, \eta_{p}^{2}=.056\right)$. These findings indicate that selected early literacy skills are sensitive to the social and cultural influences of a literacy rich environment and that the new early literacy curriculum, if implemented consistently, has the potential to contribute to their development.

On the other hand, regarding phonemic awareness, there were no significant differences between the two groups of children, despite phonological processes being targeted as part of exploring the formal characteristics of written language and written culture in the new early literacy curriculum. Unlike in the traditional approach to early literacy (SPEP, 2008), in the new early literacy curriculum (NC, 2016) phonological processes are not developed through systematic training, which involves dividing words into phonemes and blending phonemes. It is assumed that these processes develop naturally in an environment that provides opportunities to experience a wide variety of literary texts, particularly short poems, nursery rhymes and riddles ("psycholinguistic guessing games", see Goodman, 1967), which are an important foundation for inquiry and for exploring the formal characteristics of texts, including concepts of print. The absence of any differences between these two groups of children does at least show that this approach to phonological processes and phonemic awareness is effective as well. Systematic, explicit and more advanced intervention is, however, essential in the case of children with a language impairment or special needs (Tokárová \& Mikulajová, 2018).

\section{Messages for education}

Based on our interpretation of our results and in line with the current findings in early literacy development included in this study we argue in favour of effective early literacy practices. In this section will discuss early literacy practices that have a clear evidence-based foundation. 
First of all, it is indisputable that exposure to print - measured as frequency of reading and time spent reading - occurring as part of the experiences pre-school age children obtain naturally in literacy rich environments, be they in the family environment or early childhood settings, has a unique and significant impact on literacy development (Anello, 2015; Lonigan, et al., 1999; Senechal \& Young, 2008; Vivas, 1996; Zucker et al., 2013). Adult mediation in children's book reading may have an effect on this, and is the subject of extensive research activities and projects. Van Kleeck (2008), Zucker and colleagues (2013) and others recommend adult mediation, dialogic reading and discussing the text, in relation to both fiction and non-fiction, especially where these activities target extra-textual topics and questions eliciting text-based inferences are asked. Price with colleagues. (2009) observed interactions between parents and children and found that using non-fiction texts extends the time children spend reading, and that parents gave longer, more complex and more frequent feedback and commentaries, using richer and more extensive vocabularies. In addition, in dialogues about books and reading, the level of cognitive complexity increases as both parents and children use more metacognitive language. Our research shows that with appropriate metacognitive intervention and appropriate feedback, children are able to self-reflect their achievements or, more precisely, achieve higher accuracy in metacognitive monitoring (Urban, K. \& Urban, M., 2018, 2020), resulting in better overall performance (Urban \& Zápotočná, 2017).

Numerous studies, including correlation and predictive studies, have indicated that intervention targeting phonological processes have an impact on text decoding skills and spelling, while shared book reading activities contribute more to text comprehension, metacomprehension and narrative abilities over the long term (Bianco et al., 2012; Callaghan \& Madelaine, 2012).

All the reading activities mentioned and others, are vital, especially for children from socio-economically or otherwise disadvantaged backgrounds (Zápotočná, Petrová, 2017), and preschool has a role to play here. Findings on the comparable positive effect of such interventions - disregarding family environment factors (Vivas, 1996), input indicators of early literacy skills in at-risk children versus non-at-risk children (Zucker et al., 2013) and findings relating to children of immigrants from different linguistic, cultural or ethnic minorities and low-income families (Aukrust \& Rydland, 2011; Craig et al., 2003) - show that high quality early childhood education programmes can largely compensate for these disadvantages in the socio-cultural environment. 


\section{Conclusion}

The national curriculum, which has been the main research focus of this study, has been used in Slovak preschools for four years now. The concept of early literacy education, which it draws on, is based on empirical knowledge about early literacy development and emphasizes the use of reading activities such as those described in this article and many others. Since 2016, we have been conducting regular studies to monitor its impacts. Our findings, including this study, are encouraging so far, but there are several limitations to consider. Probably the most important of these is the need for longer-term assessment of the implementation of the programme. The consistency with which it is followed differs within preschools, as well as between schools. In our research, therefore, we have selected preschools displaying best practice, in ongoing projects and in cooperation with the school inspectorate. It is especially important to conduct a longer-term follow-up in school of an identical sample of children attending excellent preschools. The plan is for interdisciplinary collaboration to be conducted within a recently launched research project focusing on a wider range of pre-literate, reading, cognitive, metacognitive and information competencies in students.

\section{Acknowledgements}

This work was supported by the Scientific Grant Agency of the Ministry of Education of the Slovak Republic, grant VEGA 2/0134/18 and by the Slovak Research and Development Agency under the Contract no. APVV19-0074.

The research was approved by the ethical committee of the Institute for Research in Social Communication SAS.

\section{References}

Adams, M. (1990). Beginning to read: Thinking and learning about print. Cambridge, MA: MIT Press.

Anello, F. (2015). Narrative practices and emergent literacy: A laboratory for the development. In Ch. L. Gomez, M.A. Lopez, \& T. I. Candel (Eds.), Edulearn15 Proceedings: 7th International Conference on Education and Ne Learning Technologies (pp. 2957 - 2966).

Aukrust, V. G., \& Rydland, V. (2011). Preschool classroom conversations as long-term resources for second language and literacy acquisition. Journal of Applied Developmental Psychology, 32(4), 198-207.

Babiaková, S., \& Venzelová, J. Skúmanie detských pre konceptov o fenoménoch jazykovej a literárnej gramotnosti [Research of children's preconceptions about the 
phenomena of linguistic and literary literacy]. Gramotnost, pregramotnost a vzdèlávání, 1, 23-42.

Belešová, M. (2017). Prekoncepty detí v predškolskom veku o funkcii a procese čitania a písania [Preconceptions of Preschool Children about Functions of Writing and Reading Affects]. Gramotnost, pregramotnost a vzdělávání, 1, 7-20.

Benková, A. (2012). Development of reading comprehension skills in the conditions of the pre-primary education [Master's thesis]. Trnava University in Trnava, Faculty of Education: Department of School Education.

Bianco, M., Pellenq, C., Lambert, E., Bressoux, P., Lima, L., \& Doyen, A. L. (2012). Impact of early code-skills and oral-comprehension training on reading achievement in first grade. Journal of Research in Reading, 35(4), 427-455.

Black, A., \& Ammon, P. (1992). A developmental-constructivist approach to teacher education. Journal of Teacher Education, 43, 323-335.

Bodrova, E., \& Leong, D. J. (2006). Vygotskian perspectives on teaching and learning early literacy. In D. Dickenson, \& S. Neuman (Eds.), Handbook of research in early literacy development: Vol. 2. (pp. 243-256). Guilford Press.

Cain, K. (2003). Text comprehension and its relation to coherence and cohesion in children's fictional narratives. British Journal of Developmental Psychology, 21, 335-351.

Callaghan, G., \& Madelaine, A. (2012). Levelling the playing field for kindergarten: Research implications for preschool early literacy instruction. Australasian Journal of Early Childhood, 37(1), 13-23.

Chaplin, P. (1994). Literature webbing: Literacy across the curriculum. In P. Antonacci, \& C. Hedley (Eds.), Natural approaches to reading and writing. New Jersey: Ablex Publ. Corporation.

Chow, S.-C., Shao, J., Wang, H., \& Lokhnygina, Y. (2017) Sample size calculations in clinical research. New York: Taylor \& Francis.

Clay, M. M. (1966). Emergent reading behavior (unpublished doctoral dissertation). University of Auckland New Zealand.

Costa, S. R. (1994). Tried and true: Books that fits the interests and needs of young children. In P. Antonacci, \& C. Hedley (Eds.), Natural approaches to reading and writing. New Jersey: Ablex Publ. Corporation.

Craig, H. K., Connor, C. M., \& Washington, J. A. (2003). Early positive predictors of later reading comprehension for African American students: A preliminary investigation. Language Speech and Hearing Services in Schools, 34(1), 31-41.

Crawford, P. A. (1995). Early literacy: Emerging perspectives. Journal of Research in Childhood Education, 10, 71-86.

Destan, N., \& Roebers, C. M. (2015). What are the metacognitive costs of young children's overconfidence? Metacognition and Learning, 10(3), 347-374.

Dufva, M., Niemi, P., \& Voeten, M. J. M. (2001). The role of phonological memory, word recognition, and comprehension skills in reading development: from preschool to grade 2. Reading and Writing, 14(1-2), 91-117.

Duchovičová, J., Kováčiková, E., Khuziakhmetov A. N., \& Valeev, A. A. (2019). Phonematic awareness and chosen cognitive functions of a child. European Journal of Contemporary Education, 8, 751-760.

Ferreiro, E., \& Teberosky, A. (1982). Literacy before schooling. Exeter, NH: Heinemann. 
Ferreiro, E. (2003). Past and present of the verbs to read and write. Toronto: Douglas \& McIntyre.

Fricke, S., Szczerbinski, M., Fox-Boyer, A., \& Stackhouse, J. (2016). Preschool predictors of early literacy acquisition in German-speaking children. Reading Research Quarterly, 51(1), 29-53.

Gee, J. P. (2004). Situated language and learning. A critique of traditional schooling. New York and London: Routledge.

Goodman, K. S. (1967). Reading: A psycholinguistic guessing game. Journal of Reading Specialists, 6, 126-135.

Guziová, K. (2010/2011). Uvažujme o predprimárnom vzdelávaní spolu [Let's think about pre-primary education together]. Predškolská výchova, 65, 7-13.

Kapalková, S., \& Nemcová, M. (2020). MAIN: The Slovak version and pilot data. ZAS Papers in Linguistics, 64, 199-205.

Kim, Y. S., \& Phillips, B. (2014). Cognitive correlates of listening comprehension. Reading Research Quarterly, 49(3), 269-281.

Landerl, K., \& Wimmer, H. (2008). Development of word reading fluency and spelling in a consistent orthography: An 8-year follow-up. Journal of Educational Psychology, 100(1), 150-161.

Lonigan, C. J., Anthony, J. L., Bloomfield, B. G., Dyer, S. M., \& Samwel, C. S. (1999). Effect of two shared-reading interventions on emergent literacy skills of at-risk preschoolers. Journal of Early Intervention, 22(4), 306-322.

Lyons, K. E., \& Ghetti, S. (2011). The development of uncertainty monitoring in early childhood. Child Development, 82(6), 1178-1787.

Máčajová, M. (2019). Word to syllable analysis_of preschool children. In J. Danek, M. Sirotová, \& V. Michvocíková (Eds.), 5th international conference on language, literature and culture in education LLCE 2018, (pp. 79-100). Nümbrecht: Kirsch-Verlag. Máčajová, M., \& Zajacová, Z. (2018). Fonologické uvedomovanie vo vztahu k počiatočnému vývoju gramotnosti. In J. Duchovičová, D. Gunišová, N. Kozárová, \& R. Koleňáková (Eds.), Inovativne trendy $v$ odborových didaktikách $v$ kontexte požiadaviek praxe [Innnovative trends in subject related didactics in the context of requirement of practice], (pp. 306-312). Nitra: Univerzita Konštantína Filozofa v Nitre, Pedagogická fakulta.

Marková, M. (2011). Narrative skills survey of Slovak-speaking children aged $3-6$. [Master's thesis]. Bratislava: Comenius University in Bratislava. Faculty of Education, Department of Communication Disorders.

Mikulajová, M., Caravolas, M., Váryová, B., \& Vencelová, L. (2012). Čítanie, písanie a dyslexia s testami a normami [Reading, writing and dyslexia with test and norms]. Bratislava: Slovenská asociácia logopédov.

Mol, S. E., Bus, A. G., \& de Jong, T. (2009). Interactive book reading in early education: A tool to stimulate print knowledge as well as oral language. Review of Educational Research, 79, 979-1007.

Musiello, F. D. (1994). Creating environments that promote literacy. In P. Antonacci, \& C. Hedley (Eds.), Natural approaches to reading and writing. New Jersey: Ablex Publ. Corporation.

Petrová, Z. (2008). Vygotského škola v pedagogike [Vygotskian school in teaching]. Trnava: Typi Universitatis Tyrnaviensis. 
Petrová, Z., \& Zápotočná, O. (2018). Early literacy education in preschool curriculum reforms: the case of post-communist Slovakia. Global education review, 5, 145-159. Price, L. H., Van Kleeck, A., \& Huberty, C. J. (2009). Talk during book sharing between parents and preschool children: A comparison between storybook and expository book conditions. Reading Research Quarterly, 44(2), 171-194.

Program výchovy a vzdelávania deti v materských školách [Preschool education program]. (1999). Bratislava: MŠ SR (PEP).

Pyšná, A., \& Kapalková, S. (2012). Porovnanie hodnotenia naratívnych schopností slovensky hovoriacich detí vo veku $6-7$ rokov metódou rozprávania a prerozprávania [Comparison of narrative abilities of Slovak speaking children with using narrative production and reproduction]. Jazyk a kultúra, 10.

Revelle, G. L., Wellman, H. M., \& Karabenick, J. D. (1985). Comprehension monitoring in preschool children. Child Development, 56(3), 654-663.

Rohde, L. (2015). The comprehensive emergent literacy model: Early literacy in context. SAGE 2015, 1-11.

Saracho, O. N. (2017). Literacy and language: New developments in research, theory, and practice. Early Child Development and Care, 187, 299-304.

Senechal, M., \& Young, L. (2008). The effect of family literacy intervention on children's acquisition of reading from kindergarten to grade 3: A meta-analytic review. Review of Educational Research, 78(4), 880-907.

Štátny vzdelávací program pre predprimárne vzdelávanie - ISCED 0 [Pre-primary state education program]. (2008). Bratislava: ŠPÚ (SPEP).

Štátny vzdelávaci program pre predprimárne vzdelávanie $\mathrm{v}$ materských školách [Pre-primary state education program for preschools]. (2016). Bratislava: ŠPÚ (NC).

Street, B. V. (1984). Literacy theory and practice. Cambridge Studies on Oral and Literate Culture. Cambridge: Cambridge University Press.

Street, B. V. (1997). The implications of the "New Literacy Studies" for literacy education. English in Education, 31, 45-59.

Sulzby, E. (1992). Transition from emergent to conventional writing. Language Arts, 69, 290-297.

Tokárová, O., \& Mikulajová, M. (2018). Vplyv tréningu fonematického uvedomovania v predškolskom veku na osvojovanie čitania a písania [The effect of phonological awareness training in preschool age on reading and spelling skills] In: M. Mikulajová (Ed.), Utváranie ranej gramotnosti $v$ norme a patológii [Early literacy formation in norm and pathology], (pp. 137-188). Brno: Institut vzdělávání Sokrates.

Torppa, M., Georgiou, G. K., Lerkkanen, M.-K., Niemi, P., Poikkeus, A.-M., \& Nurmi, J.-E. (2016). Examining the simple view of reading in a transparent orthography: A longitudinal study from kindergarten to grade 3. Merrill-Palmer Quarterly, 62(2), 179-206.

Urban, K. (2017). Metakognitivny monitoring [Metacognitive Monitoring]. In O. Zápotočná, \& Z . Petrová. Raná jazyková gramotnost’ detí zo sociálno-ekonomicky znevýhodñujúceho prostredia [Early literacy of children from socially disadvantaged environments], (pp. 79-98). Trnava: Typi Universitatis Tyrnaviensis.

Urban, K., \& Urban, M. (2018). Influence of Fluid Intelligence on Accuracy of Metacognitive Monitoring in Preschool Children Fades with the Calibration Feedback. Studia Psychologica, 60(2), 123-136. 
Urban, K., \& Urban, M. (2020). Effects of performance feedback and repeated experience on self-evaluation accuracy in high- and low-performing preschool children. European journal of psychology of education.

Urban, K., \& Zápotočná, O. (2017). Metakognitivnny monitoring pri riešení verbálnych a neverbálnych úloh u detí predškolského veku [Metacognitive Monitoring in Preschool Children Solving Verbal and Nonverbal Tasks]. Československá psychologie, LXI(6) 521-535.

van der Wilt, F., Boerma, I., van Oers, B., \& van der Veen, Ch. (2019). The effect of three interactive reading approaches on language ability: an exploratory study in early childhood education. European Early Childhood Education Research Journal, 27, 566-580.

Van Kleeck, A. (1995). Emphasizing form and meaning separately in prereading and early reading instruction. Topics in Language Disorders, 16, 27-49.

Van Kleeck, A. (1998). Preliteracy domains and stages: Laying the foundations for beginning reading. Journal of Children's Communication Development, 20, 33-51.

Van Kleeck, A. (2008). Providing preschool foundations for later reading comprehension: The importance of and ideas for targeting inferencing in storybook-sharing interventions. Psychology in the Schools, 45(7), 627-643.

van Kleeck, A. (2014) Intervention activities and strategies for promoting academic language in preschoolers and kindergartners. Journal of Communication Disorders, Deaf Studies \& Hearing Aids, 2(4), 126.

Vivas, E. (1996). Effect of story reading on language. Language Learning, 46(2), 189216.

Zápotočná, O. (2004). Kultúrna gramotnost’ v sociálnopsychologických súvislostiach [Cultural literacy in sociopsychology contexts]. Bratislava: Album.

Zápotočná, O. (2013). Metakognitivne procesy v čitaní, učení a vzdelávaní. [Metacognitive processes in reading, learning and education]. Trnava: Typi Universitatis Tyrnaviensis.

Zápotočná, O. (2017). Porozumenie textu [Text comprehension]. In O. Zápotočná, \& Z. Petrová (Eds.) Raná jazyková gramotnost' detí zo sociálno-ekonomicky znevýhodñujúceho prostredia [Early literacy of children from socially disadvantaged environments], (pp. 32-54). Trnava: Typi Universitatis Tyrnaviensis.

Zápotočná, O., \& Petrová, Z. (Eds.) (2017). Raná jazyková gramotnost’ detí zo sociálno-ekonomicky znevýhodñujúceho prostredia [Early literacy of children from socially disadvantaged environments]. Trnava: Typi Universitatis Tyrnaviensis.

Zápotočná, O., \& Petrová, Z. (2017). Indikátory ranej jazykovej gramotnosti u detí zo sociálne znevýhodñujúceho prostredia [Early literacy indicators in case of children from socially disadvantaged environments]. In O. Zápotočná \& Z. Petrová (Eds.) Raná jazyková gramotnost' detí zo sociálno-ekonomicky znevýhodñujúceho prostredia [Early literacy of children from socially disadvantaged environments], (pp. 13-31). Trnava: Typi Universitatis Tyrnaviensis.

Zucker, T. A., Cabell, S. Q., Justice, L. M., Pentimonti, J. M., \& Kaderavek, J. N. (2013). The role of frequent, interactive prekindergarten shared reading in the longitudinal development of language and literacy skills. Developmental Psychology, 49(8), 1425-1439. 


\section{Authors}

Zuzana Petrová, associate professor

Institute for Research in Social Communication

Slovak Academy of Sciences

Dubravska cesta 9

84511 Bratislava

Slovakia

E-mail:zpetrova@savba.sk

Trnava University

Faculty of Education

Department of School Education

Priemyselná 4

91843 Trnava

Slovakia

Ol'ga Zápotočná, professor

Institute for Research in Social Communication

Slovak Academy of Sciences

Dubravska cesta 9

84511 Bratislava

Slovakia

E-mail: zapotocna@savba.sk

Trnava University

Faculty of Education

Department of School Education

Priemyselná 4

91843 Trnava

Slovakia

Kamila Urban, PhD.

Institute for Research in Social Communication

Slovak Academy of Sciences

Dubravska cesta 9

84511 Bratislava

Slovakia

E-mail:kamila.urban@savba.sk

Charles University

Faculty of Arts

Department of Psychology

Jan Palach Square 1/2

11638 Prague 1

Czech Republic

Marek Urban, Ph.D.

Jan Evangelista Purkyne University

Faculty of Art and Design 
Department of History and Theory of Art

Pasteurova 9

40096 Usti nad Labem

Czech Republic

E-mail:marek.m.urban@gmail.com 